\title{
Diflavonols as single emitters for polymer-based WOLEDs
}

\author{
V.V.Kosach ${ }^{1}$, V.G.Pivovarenko ${ }^{2}$, V.M.Yashchuk ${ }^{1}$ \\ ${ }^{1}$ Faculty of Physics, T.Shevchenko National University of Kyiv, \\ 2 Glushkov Ave., 03022 Kyiv, Ukraine \\ ${ }^{2}$ Faculty of Chemistry, T.Shevchenko National University of Kyiv, \\ 12 L.Tolstoy Str., 01033 Kyiv, Ukraine
}

\section{Received February 22, 2016}

\begin{abstract}
The spectral peculiarities of polymer/dye solid mixtures on the base of PEPCa polymer (polyepoxypropylcarbazole) as matrix and DFOM (3,7-dihydroxy-2,8-diphenyl-4H,6H-pyrano[3,2-g] chromene-4,6-diones) as emitter were investigated. Peculiarities intramolecular proton transference after the excitation of molecule, incident to this material, allows one to create emitting layer with emission spectrum close to white light and using only one luminophore. Spectral behavior of investigated compounds proves the presence of excitation energy transfer from the PEPCa matrix to the DFOM molecules, which is necessary for effective use of the excitation energy and forming luminescence curve needed. Luminescence of the investigated films demonstrates color characteristics CRI 54 and CIE $(0.33,0.42)$ which gives a possibility to consider such systems as promising in the context of developing White OLED emitters.
\end{abstract}

Keywords: WOLED, diflavonols, ESIPT, organic light-emitting devices.

Исследованы спектральные особенности твердых смесей полимер/краситель на основе полимера ПЕПК (полиэпоксипропилкарбазол) в качестве матрицы и DFOM ((3,7-dihydroxy-2,8-diphenyl-4H,6H-pyrano[3,2-g] chromene-4,6-diones)) в качестве люминофора. Механизм внутримолекулярного переноса протона после возбуждения молекулы, свойственный этому материалу, позволяет получить излучающий слой со спектром излучения, близким к белому свету, используя при этом лишь один люминофор. Спектральное поведение исследованных систем позволяет предположить присутствие в них переноса энергии электронного возбуждения от матрицы ПЕПК к молекулам люминофора DFOM, что необходимо для әффективного использования энергии возбуждения и формирования заданного контура люминесценции. Люминесценция исследованных пленок продемонстрировала цветовые характеристики CRI 54 и CIE $(0.33,0.42)$, что позволяет рассматривать подобные системы, как перспективные при создании "белых" OLED-излучателей.

Використання діфлавонів в якості сдиного випромінювача для полімерних "білих" OLED пристроїв. В.В.Косач, В.Г.Півоваренко, В.М.Ящук.

Досліджено спектральні особливості твердих сумішей полімер/барвник на основі полімеру ПЕПК (поліепоксипропілкарбазол) в якості матриці та сполуки DFOM (3,7-dihydroxy-2,8-diphenyl-4H,6H-pyrano[3,2-g] chromene-4,6-diones) в якості люмінофора. Механізм внутрішньомолекулярного трансферу протону після збудження молекули, властивий цьому матеріалу, дозволяє отримати випромінюючий шар зі спектром випромінювання, близьким до білого світла, використовуючи лише один люмінофор. Спектральна поведінка досліджених систем дозволяє припускати наявність у них перенесення енергії електронного збудження від матриці ПЕПК до молекул барвника DFOM, що необхідно для ефективного використання енергії збудження та формування необхідного контуру люмінесценції. Люмінесценція досліджених плівок продемонструвала кольорові характеристики CRI 54 та CIE $(0.33,0.42)$, що дозволяє розглядати подібні системи, як перспективні у створенні "білих" OLED-випромінювачів. 


\section{Introduction}

While in last two decades the OLED technology has impressively "grown up" and gained some success on electronics markets, the development of efficient White OLEDs (or WOLED) with good color characteristics remains an actual challenge. So it is still important to obtain new materials which would have a potential to improve the technology.

There are a number of problems in the WOLED development. If we use an organic matrix as light emitting layer with incorporated 2 or 3 molecular emitters, the following problems appear: (1) inhomogeneous distribution of emitting centers of different types in the matrix, which is related to different solubility in solutions for film casting (spin-coating technology) or different evaporating ability (evaporating technology), or other peculiarities of WOLED film preparation technologies); (2) the difference in energy transfer efficiency from the matrix to emitting centers of different types. These problems, from our point of view, could be overcome using single-molecular emitters possessing luminescent ability in a wide spectral range covering the entire visible region. In this context compounds with the intramolecular proton transfer represent a great potential because of their potential ability to form nearly "white" luminescence curve by themselves, with no additional luminophores [1]. One of the potentially useful classes of molecules of this kind are aminoxanthones, which have been already well studied [2]. Another promising class of such type of compounds for WOLED is flavonols. The photoinduced transfer of the proton that takes place in such molecules in some cases allows the emission spectrum to cover all the visible range of light spectrum. Thus, some simple single-layer polymer/dye systems could be made on the base of flavonol molecules with emission spectrum close to the white light.

\section{Experimental}

All measurements were performed at room temperature and ambient atmosphere. All solutions were prepared in dioxane as solvent, with concentration $c=10^{-5} \mathrm{~g} / \mathrm{ml}$. Films were made from the solution by spincoating on a glass substrate. For obtaining of PEPCa(polyepoxypropylcarbazole) + DFOM(3,7-dihydroxy-2,8-diphenyl- $4 \mathrm{H}, 6 \mathrm{H}$ pyrano[3,2-g] chromene-4,6-diones) films, a mixture of PEPCa and DFOM solutions was prepared and then spin-coated on a glass substrate. The mass fraction of DFOM in the resulting solid mixture film was $1 \%$ (with respect to the PEPCa mass). For spincoating of the films, we used a laboratorymade device which rotated a glass substrate with the solution at frequency $3000 \mathrm{rpm}$ $(50 \mathrm{~Hz})$ for nearly 10 sec.

The absorption spectra were measured on Specord UV-Vis spectrophotometer. The luminescence and luminescence excitation spectra were measured on Cary Eclipse fluorometer (Varian).

For calculation of CIE coordinates we used the most widely used standard of year 1931 [3, 4]. Calculations of CRI index were carried out using the method and software developed by Ohno and Davis [5, 6]. Because of software specifications, CRI values were obtained from the $380 \mathrm{~nm}-780 \mathrm{~nm}$ range of the luminescence curve.

\section{Results and discussion}

In our study we investigated spectral behavior of 3,7-dihydroxy-2,8-diphenyl4H,6H-pyrano[3,2-g] chromene-4,6-dione (DFOM) compounds (Fig. 1) solutions and their solid mixtures (films) with PEPCa polymer as a matrix. DFOM molecule is related to the class of diflavonols in which the process of proton transfer after excitation of the molecule can take place [7-10]. Such proton transfer process is typically named as Excited-State Intramolecular Proton Transfer or ESIPT [7, 9-11]. Such intramolecular proton transfer in diflavonols leads to three possible tautomeric forms of the diflavonol molecule: NN, NT and TT [12-14]. At present, it is believed that the diflavonols exist in the $\mathrm{NN}$ form in the ground state and in the $\mathrm{NN}^{*}$ and $\mathrm{NT}^{*}$ forms in the excited state $[13,15]$.

Both absorption and luminescence (Fig. 2) spectra of DFOM + PEPCa solution $\left(m_{\% \mathrm{PEPCa}} \sim 1 \%\right)$ suggest the presence of two main optical centers: typical carbazolelike center with clearly structured absorption peaks on $295 \mathrm{~nm}, 330 \mathrm{~nm}, 346 \mathrm{~nm}$ and luminescence peaks at $351 \mathrm{~nm}$ and $367 \mathrm{~nm}$. The second one is a typical flavonol-like optical center with a wide absorption peak near $363 \mathrm{~nm}$ and wide luminescence peak near $570 \mathrm{~nm}$. Both centers take part in absorption and emission of light in the DFOM solutions.

In the luminescence of the PEPCa + DFOM film, an additional comparable peak near $480 \mathrm{~nm}$ appears. Since PEPCa has no sufficient fluorescence peaks in this spec- 


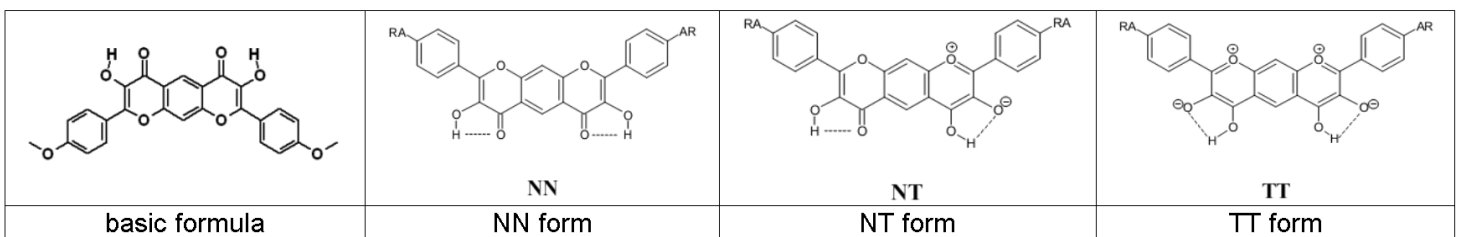

Fig. 1. DFOM molecule [15].

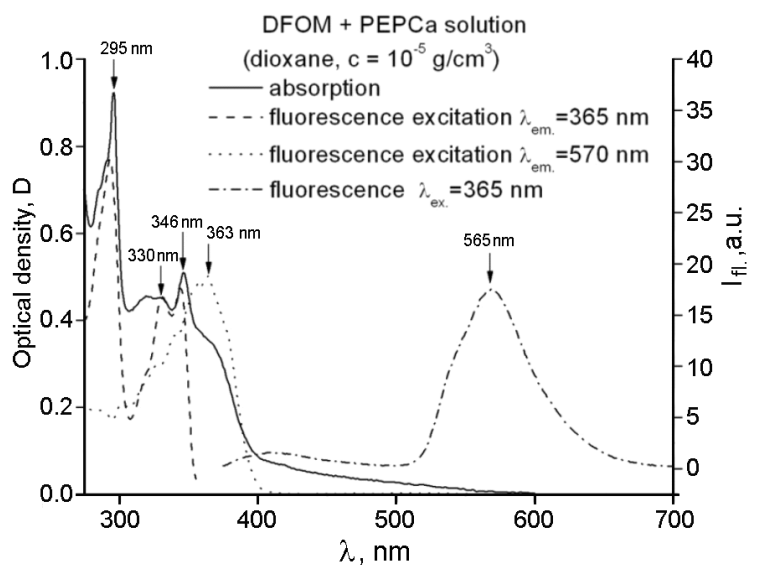

Fig. 2. Absorption, fluorescence and fluorescence excitation spectra of DFOM + PEPCa solution $\left(m_{\% \text { PEPCa }} \sim 1 \%\right)$.

tral region, we consider both $479 \mathrm{~nm}$ and $555 \mathrm{~nm}$ peaks to be the result of different tautomeric DFOM forms emission [16]. It is worth to mention that fluorescence excitation spectra for all significant peaks of PEPCa + DFOM luminescence are almost identical to the absorption spectrum of pure PEPCa. These allow us to consider the presence of effective excitation energy transfer from PEPCa to DFOM molecules.

Color parameters CIE and CRI for the investigated PEPCa + DFOM film luminescence were estimated (for the $\lambda_{e x}=330 \mathrm{~nm}$ luminescence curve): $\operatorname{CIE}(0.33 ; 0.42)$ and $\mathrm{CRI}=54$. Such values are pretty close to color parameters of existing white light sources, and thus such films could be considered as potentially promising for the development of White OLEDs.

To examine the hypothesis of energy transfer from the luminescence data of the films studied, the luminescence excitation and absorption spectra of the matrix, dopant and resulting solid mixture should be compared. Absorption and luminescence excitation spectra of the solid mixture film (Fig. 3) in the 330-350 nm range are similar to the PEPCa film absorption spectrum (Fig. 4). This allows us to consider PEPCa molecules as main absorbing optical centers in the PEPCa + DFOM film. At the same

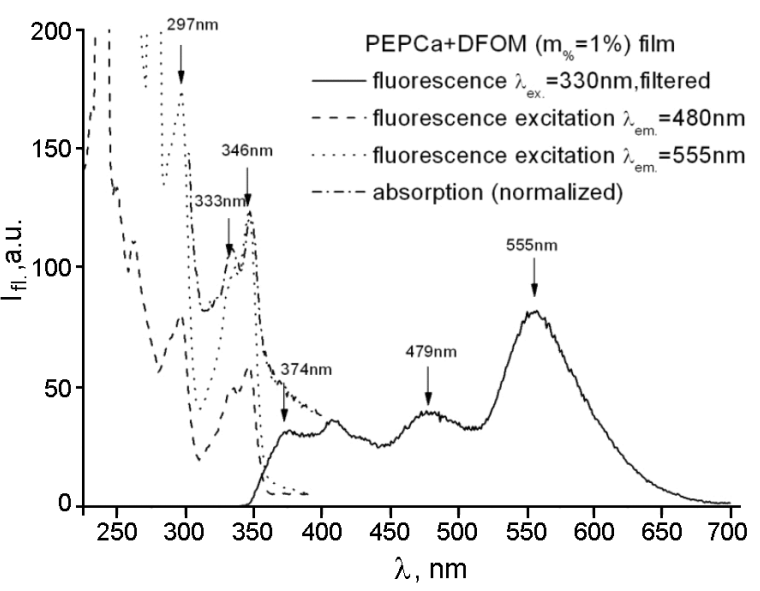

Fig. 3. Fluorescence, fluorescence excitation and absorption spectra (normalized) of PEPCa + DFOM film.

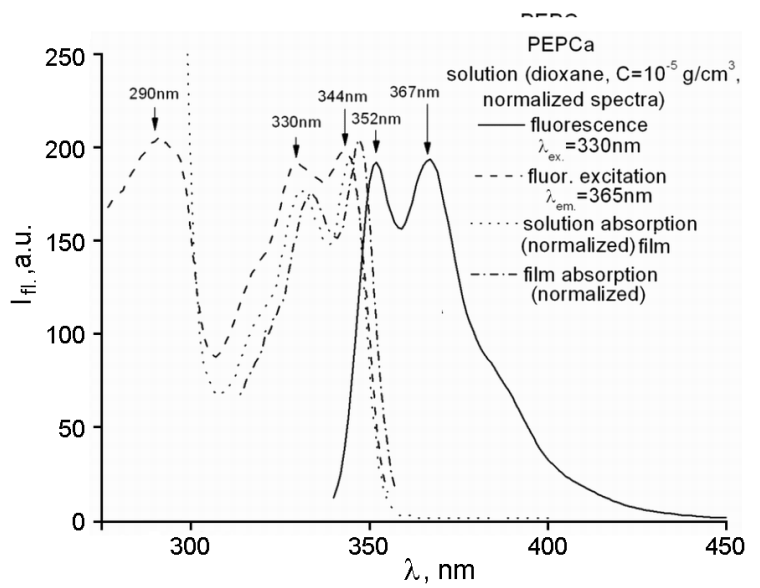

Fig. 4. Absorption, fluorescence and fluorescence excitation spectra (normalized) of PEPCa.

time in the luminescence spectrum of the solid mixture all optical centers, i.e., PEPCa and DFOM in different forms, are presented with comparable intensities. From this data we can conclude that DFOM molecules in the mixed films emit light mainly due to excitation energy transfer from PEPCa to DFOM molecules.

\section{Conclusions}

In the present investigation the spectral properties of PEPCa + DFOM were studied. Analysis of the obtained spectral data al- 
lows us to consider the presence of excitation energy transfer from the polymer matrix to luminophore in the investigated PEPCa/DFOM films. Also it was shown that sufficient luminescence color characteristics (CRI 54 and CIE $(0.33,0.42)$ ) of a single emitting layer could be obtained using DFOM molecule as emitter and PEPCa polymer as matrix.

So, the results obtained demonstrate the possibility to develop white OLED with one type of light-emitting molecules, the excitation of which is realized by migration of the mobile electronic excitation through a suitable organic matrix. The coverage of the visible spectral region is provided by different tautomers that appear due to intramolecular proton transfer in excited states of flavonol molecules.

\section{References}

1. H.-Ch.Peng, Ch.-Ch.Kang, M.-R.Liang et al., ACS Appl.Mater. Interfaces, 3, 1713 (2011).

2. V.G.Syromyatnikov, V.M.Yashchuk, T.Yu.Ogul'chansky et al., J. Luminescence, 9, 93 (1999).

3. Commission Internationale de l'Eclairage Proceedings, Cambridge University Press, Cambridge (1932).
4. Th.Smith, J.Guild, Trans. Opt. Soc., 33, 73 (1931-32).

5. W.Davis, Y.Ohno, Opt. Engin., 49, 0336022 (2010).

6. Yoshi Ohno, Opt. Engin., 44, 111302 (2005).

7. P.K.Sengupta, M.Kasha, Chem.Phys. Lett., 68, 382 (1979).

8. A.Sytnik, D.Gormin, M.Kasha, in: Proc.. Nat. Acad. Sci. USA, 91, 11968 (1994-+).

9. S.Basu, S.Mondal, D.Mandal, J.Chem.Phys., 034701, 132 (2010).

10. S.Ash, S.P.De, H.Beg, A.Misra, Mol.Simulation, 37, 914 (2011).

11. A.P.Demchenko, Introduction to Fluorescence Sensing, Springer Science+Business Media B.V. (2009).

12. V.G.Pivovarenko, L.Jozwiak, J.J.Blazejowski, Org. Chem., 23, 3979 (2002).

13. E.Falkovskaia, V.G.Pivovarenko, J.C.del Valle, Chem. Phys. Lett., 352, 415 (2002).

14. A.D.Roshal, V.V.Moroz, A.Wroblewska, J.Blazejowski, J.Org.Chem., 68, 5860 (2003).

15. V.V.Moroz, A.D.Roshal, V.G.Pivovarenko, Kharkov Univ. Bull., Chem. Sci., 14, 59 (2006).

16. V.V.Moroz, A.G.Chalyi, I.E.Serdiuk et al., J. Phys. Chem.A, 117, 9156 (2013). 